\title{
Understanding the Fanboy Culture; Their Place and Role within the Games Industry
}

Conference Paper · September 2015

READS

71

\section{2 authors:}

\section{Bradley James}

Staffordshire University

4 PUBLICATIONS 2 CITATIONS

SEE PROFILE
Bobbie Fletcher

Staffordshire University

8 PUBLICATIONS 4 CITATIONS

SEE PROFILE

Some of the authors of this publication are also working on these related projects: 


\title{
Understanding the Fanboy Culture; Their Place and Role within the Games Industry
}

\author{
Bradley James, B.D.Fletcher
}

\begin{abstract}
Within Video Game culture very few slights carry as much weight and disrespect as being called a 'Fanboy'. Few understand what this term means and fewer have explored the role this type of consumer plays in the gaming industry, let alone their significant cultural impact. This paper seeks to understand and define what a Fanboy is using various social and psychological theories and discusses their use within the industry. This is done via analysing recent events and new media technologies in conjunction with multiple gaming franchises recent releases. It then evaluates the image of the Fanboy in popular culture, how it is has changed thanks to new methods of engagement with new strategies and brand types while acknowledging their limitations within their wider social cultures across the world.
\end{abstract}

Key Words: Video game culture, fanboy, brand loyalty, Youtube, cultural impact, game studies, social culture.

$* * * * *$

\section{Introduction}

The term Fanboy is thrown around a lot within various social groups; especially when it comes to video games. Yet for how much it is mentioned, few seem to understand what it means. The official definition is as follows; a male/female fan, especially one who is obsessive about comics, music, film, or science fiction. Note use of the word obsessive, companies naturally love when their consumers become obsessive of a product as it then becomes that much easier to sell to them; they view the brand relationship with a biased stance leading to a devaluation of any alternative.

By examining a brand/product to see why consumers become so attached, S. Fournier found that one of the most important factors is that the consumer creates a relationship with their product. ${ }^{1}$ After numerous case studies with various subjects, Fournier concluded the following; Love and Passion were two key words that the subjects used as descriptive terms for their preferred brands. The subjects also displayed high levels of commitment, interdependence and intimacy (in such a way that they could be compared to a physical relationship) towards the products, leading to a summation that the research undertaken has implications for areas outside the consumer-brand domain (for marketing etc.). This could be done via us of a model of brand relationship quality (and its effects on relationship stability) generated from the results of Fournier's work. 
In the stance of someone becoming a Fanboy; thus taking the consumer-brand idea even further, we have a delicate situation to consider. As discussed by S. Locke, being a Fanboy can also be used for self-description, one used in social circles to assert control over social activity(s) and/or as shield against varying levels of critique. ${ }^{2}$ Locke examined that his subjects willingness to grasp at frankly what most would could consider a paradox and outwardly declare themselves Fanboys was and still is a revolutionary action, for example in the case of comic book readers. The question we should then ask ourselves, before creating a Fanboy, is the following: Should we? Are Fanboys a good thing?

When it comes to the gaming industry there is no denying that it has had an extremely bad reputation in the, for lack of a better term, more uneducated side of society with many studies and cases focusing on the more negative side of what the medium can produce. The American Psychological Association's stance on this subject, to this is day, is that games increase aggressive behaviour and thoughts, angry feelings, physiological arousal, and decreases helpful behaviour while also encouraging violence towards women, rape myth acceptance and anti-women attitudes (based on numerous studies collected by the association). ${ }^{3}$

When examining the aforementioned area, the same words we see from Fournier's work appear again but are twisted into something more grotesque. Love and passion becomes obsession and addiction, loyalty and skill becomes disgrace and inability; the mere act of caring about something so much to even start to become a dedicated fan seems to mean that you have to walk a dangerous line that can easily be crossed and supposedly lead to a more sinister path. ${ }^{4}$ While it would be helpful to this case to insist that the previous works are unfounded it does in fact ring true in some cases. Numerous events in recent years have revealed the darker side of what was initially thought to be the dark side of gamers to the public, being reported in various social media across the internet. However, on closer inspection, the crux of the decadence stemmed from the Fanboys surrounding the media in relation with the incident.

It would seem then that Fanboys of video games are much more susceptible to creating an emotional attachment to their preferred media and thus leads them to become the perceived aggressive stereotype that, originally, studies showed them to be. The levels of depravity that gamers can sink to are astonishing and a negative attitude or frustration fuelled by the unrelenting desire to defend ones love is a scary combination. It should be noted here that this is only a small percentage of gaming consumers; the Fanboy status is not something that players are labelled with easily and this behaviour is constantly associated with them. In recent years more studies have started to show that, among the average gamer, games in fact increased helpful prosocial behaviour. ${ }^{5}$ Other studies concluded that video games do not increase or reduce prosocial behaviour as they fail to replicate results based on previous studies in the area. ${ }^{6}$ Some studies make the case that games only cause aggression to players 
in with a pre-existing disposition, whether psychological or physical; something that a defined Fanboy is seen to have. ${ }^{7}$

Based on these discoveries, we can propose the following; the key factor in creating a Fanboy is making an engaging and, whether it is perceived to be or actually is, in depth product which allows the consumer to be lost in the medium, so much so that they are affected by it to an extent which could be deemed almost unhealthy. It is at this stage that, along with some pandering and appropriate marketing, you have all the ingredients to formulate the perfect consumer; ready and willing to buy your products based on a warped view of your previous endeavours.

\section{The New Revolution}

In recent years there has been an astounding rise of Youtube personalities interacting with the games industry in terms of gameplay showcases, reviews and satirical shows. These online productions have reached such notoriety now that they actively affect the industry that they initially were a part of; one of the most prominent examples being PewDiePie. ${ }^{8}$ Real name Felix Kjellberg, PewDiePie is the most influential Youtubers ever with, as of 2015, well over 33 million subscribers to his channel and an avid fan base, referred to as his Bro Army.

As you can expect, with over 30 million viewers his videos garner a lot of weight in fanbases and the general populous. Using Diffusion of Innovation theory, we can see that PewDiePie is defined as an innovator; he can do and play what he wants on his channel with little to no risk to his shows and thus is ahead of social curves. ${ }^{9}$ This leads to a surge of other popular personalities picking up the games PewDiePie plays (thus making them 'Early Adopters'; other prominent but less risk taking types) and their fans being showcased the game(s) as well. This trend continues and suddenly a large amount of consumers are playing or talking about the product across the whole spectrum of consumer types.

These Youtubers are now far more influential than your average celebrities; and as such create a new variation of Fanboy, one that is just as vocal and loyal but also willing to change and absorb anything that their idols play. ${ }^{10}$ Perhaps the best examples of this phenomenon are Skate 3and Flappy Bird. ${ }^{11}$ Skate 3 was initially released for the PlayStation 3 and Xbox 360 in 2010 and received average scores from reviewers. ${ }^{12}$ Since then it remained your average sports game title for the last generation consoles and ceased production after a year or so. Suddenly, in 2014, PewDiePie releases a series of videos with him playing Skate 3 showcasing glitches, bugs and general amusing sections of the title. This suddenly caused a huge demand for the game from Felix's fans causing video game retailers to request the game to be re-produced. ${ }^{13}$ The game then sat in the top 40 charts all through the rest of the year; an astonishing feat for a 4 year old title.

But perhaps the best example is the aforementioned Flappy Bird; a poorly made yet addictive title released on smartphones in May 2013. It remained on the app store for months until January 2014 when PewDiePie uploaded 'FLAPPY BIRD - DON'T 
PLAY THIS GAME'. ${ }^{14}$ Thanks to this video the game received a massive popularity spike and, subsequently, thousands of downloads thrusting the game into ridiculous levels of popularity. This spike meant that the creators of the game ended up earning on average $\$ 50,000$ per day via in-app advertising after 50 million downloads (as of February 2014). ${ }^{15}$

However, referring back to Fournier's conclusion, that love and passion are key to creating a purchasable product, you notice that this is not here. These titles were not bought out of a love for the product but out of the love of it from another. From this we can conclude that these online personalities turn themselves into a beloved brand which then, via a devoted consumer base, can funnel said consumers towards specific products which then, by sheer numbers, create an unsettling demand for said product. Flappy Bird was and is not a good game receiving mediocre reviews and being obnoxiously difficult. ${ }^{16}$ But, thanks to its fame, it still commanded such obsession that even when the game was removed from the app stores due to its obscene popularity, some consumers ended up purchasing phones from eBay with the game installed on it from prices up to and including $\$ 900 .{ }^{17}$ This is a type of loyalty that cannot be ignored or explained away as a one off; the admiration replaces the love that Fournier initially said was needed. ${ }^{18}$

\section{The Fanboy's Place in the Industry}

We have established two key things; a Fanboy is created when the love of a Product or Brand becomes so intense that the subject in question believes in the product regardless of quality or criticism and that Fanboys create a large demand for products like the ones they have become engaged in. There is at this point no denying the temptation to create this type of consumer.

Based on the previous points, companies across the industry have already been employing various strategies to create this fan type. One of the more popular approaches unconsciously drew from the Youtuber method; making a personality sell the product. A big example of this involved the recent Metal Gear Solid titles, their designer Hideo Kojima and his subsequent company, a subsidiary of Konami. ${ }^{19}$ Kojima Productions is a giant advertisement in itself for the games it is attached to; fans know of Hideo Kojima and his work and are therefore more willing to buy brands this person is attached too.

While the Kojima name draws in the consumer this does not necessarily differentiate them from the average fan; what does that are the products themselves. The Metal Gear series in particular has been generally well received across various titles but what is relevant here are the titles that were considered 'worse' games, namely the Metal Gear Acid series and the more recent Metal Gear Solid V: Ground Zeroes. $^{20}$ These titles were different from the average Metal Gear game and this initially could cause a problem; naturally, change is not something that a consumer often likes. As discussed by A. Bandura, people like to have control over their own 
lives, change is too chaotic and control is preferred '... because it provides countless personal benefits' ${ }^{21}$

The differences caused these games to be reviewed rather harshly from various online sites which in turn caused rifts within the fanbase of the series. Fans of the series did not mind the changes; they believed in Kojima, and due to this strong attachment, fought against the reasonable arguments. ${ }^{22}$ This phenomenon can be explained by Bass who stated that the probability that an individual will adopt the innovation or change (with a product) is linear with respect to the number of previous adopters; since so many fans believed in the brand, any change did not and could not matter. $^{23}$

This is how these fans actively affect the industry; they force, unknowingly or not, developers into making decisions to please fans. This results in a variety of problems and is prevalent in larger companies as well. The Sonic the Hedgehog series is a perfect example of everything previously discussed. The Sonic the Hedgehog character has been around since 1991 and since that time has amassed a large and extremely dedicated fanbase of players from around the world. This is largely due to its rather strong starting set of games; Sonic the Hedgehog 1, 2, 3, Sonic and Knuckles and Sonic CD, games that are still played and loved to this day. ${ }^{24}$ These titles solidified Sonic into the minds of gamers and created that important emotional attachment to SEGA, mostly due to the infancy of the games industry, but still a strong connection nonetheless.

The rivalry to the already popular Mario series from Nintendo was the final push to make sure that these two characters and their games became not only gaming icons, but cultural icons worldwide. However, during the advent of three dimensional gaming, these games and their admirers had a drastic change due to changes in gameplay and platforms.

This started an unpopular trend, coined as the Sonic Cycle by fans, of Sonic games being highly anticipated when announced and the steadily more hated until release when the games would then inevitably be slammed, regardless of quality and/or value. While this behaviour could be seen as a more negative state for fans to exist in, it is in reality something brought on by the Fanboys. The wish of a 'perfect' Sonic game on announcement creates a high level of expectation and when the game cannot match this level it is perceived as bad.

The most apt example of this phenomenon can be seen in the most recent title in the Sonic series, Sonic Boom: Rise of Lyric. ${ }^{25}$ This title on its initial announcement excited and frightened fans in equal measures but the hype was still present. As more of the game has been shown, the Fanboys, as well as the rest of the fanbase, tore the game apart from every angle; so much so that all expectations of the game to be good hit rock bottom. ${ }^{26}$ Nevertheless, throughout all the criticism, these Sonic titles still sell well because of their loud and critical fanbase; keeping the standards low and anticipation high sells the product - fuelled partly by the love-hate relationship with fans. ${ }^{27}$ 


\section{Conclusions}

It is undisputed that obsessive and passionate fans actively change and influence the industry; they are a continuous source of not only revenue but also advertisement and design. The usage of this consumer type is a fair one. Companies need to make money to continue to produce their product. However, it is obvious that the games industry is underusing these players potential. As theorised by J. McGonigal:

Gamers are the most collaborative people on earth... as a result of the industry's relentless focus on innovating new ways to cooperate, coordinate and cocreate, many gamers are developing a new set of collaboration superpowers that transcend what they are capable of doing in the real world. ${ }^{28}$

This view is supported by M. Flanagan who concludes that:

Games are an exercise in social engineering mechanisms for such social mechanisms are inherent in the game goals interaction styles and architecture of each and every game ... we can help make systems that change things. ${ }^{29}$

With this in mind, it raises a question; due to gaming's strange cultural standpoint, why has it never been a priority to change the general populous' view on game cultures? In Western countries, games and the people who play them are still seen in a negative light. This is highlighted via the Gamergate controversy. In an extremely prominent piece published during the event, L. Alexander confirms this;

(Game culture) is a petri dish of people who know so little about how human social interaction and professional life works that they can concoct online 'wars' about social justice or 'game journalism ethics,' straight-faced, and cause genuine human consequences. Because of video games. ${ }^{30}$

This attitude is not exclusive to the Western territories. The Japanese term Otaku generally incurs the same treatment as Fanboy; being a socially inept individual with a passion which few understand, in this case, incorporating gaming, anime and manga. As M, Hills describes, these terms, Otaku and Fanboy, have become devalued in culture due to their negative implications calling it 'an attempt to naturalise fan identities by implying that fandom is a transnational/transcultural experience'. ${ }^{31}$

It is now we hit an impasse; Fanboys are a natural phenomenon, they cannot be effectively manufactured (even with assistance) but are created at a consistent rate 
enough to generate cultural noise which, in turn, gives the Fanboy a negative image but also drives sales. Something has to give and it would seem, based on pre-existing cultural norms, the general populous will buckle first. The advent of all popular media types, radio, television and film, during their early stages were (and still are) surrounded by criticism but now are considered normal. M. Csikszentmihalyi et al concludes that visual media (focusing on television) which give us events to absorb, command 'undivided attention and we respond almost as if we were there' and that after a while this becomes part of the sameness of the vast television landscape'. ${ }^{32}$ This is furthered by G. Gerbner et al who concludes that visual media has become a common symbolic environment thanks to growing up and living with it, and consequently creates 'the cultivation of stable, resistant and widely shared assumptions, images and conceptions reflecting the institutional characteristics and interest of the medium itself' ${ }^{33}$

Perhaps then it is the destiny of gaming Fanboys to eventually be accepted into culture as naturally as other types are. However we cannot be sure as, like other visual media industries; games are still too young to have had the cultural acceptance that seems to be inevitable. The only question left is to discover what types of games will generate the fans that will eventually define the cultures they will fit into. Further examination into the specifics of worldwide gaming cultures would need to be developed to see where this consumer type could fit in and how, if at all, they could affect it.

\section{Notes}

${ }^{1}$ Susan Fournier, 'Consumers and Their Brands: Developing Relationship Theory in Consumer Research', Journal of Consumer Research 24 (1998): 343-352, viewed January 2015 , http://www.jstor.org/stable/pdfplus/10.1086/209515.pdf?acceptTC=true\&jpdConfi rm=true \&

${ }^{2}$ Simon Locke, '"Fanboy" as a Revolutionary Category', Journal of Audience \& Reception Studies 9, issue 2 (2012): 835-854, Viewed January 2015, http://www.participations.org/Volume\%209/Issue\%202/Locke.pdf

${ }_{3}^{3}$ American Psychological Association, Resolution on Violence in Video Games and Interactive Media, (2005) Viewed January 2015, http://www.apa.org/about/policy/interactive-media.pdf

${ }^{4}$ Paul Dean, 'Tropes vs Women in Video Games: Why it Matters' IGN, $31^{\text {st }}$ May 2013, Viewed January 2015, http://uk.ign.com/articles/2013/05/31/tropes-vswomen-in-video-games-why-it-matters

${ }^{5}$ Douglas A Gentile et al., 'The Effects of Prosocial Video Games on Prosocial Behaviors: International Evidence from Correlational, Longitudinal, and Experimental Studies', Pers Soc Psychol Bull. 35 (2009): 752-763, Viewed January 
2015 , http://www.ncbi.nlm.nih.gov/pmc/articles/PMC2678173/pdf/nihms-

104172.pdf

${ }^{6}$ Morgan J Tear and Mark Nielson, 'Failure to Demonstrate That Playing Violent Video Games Diminishes Prosocial Behavior', PLOS ONE Journal DOI: 10.1371/journal.pone.0068382 (2013) Viewed January 2015 , http://journals.plos.org/plosone/article?id=10.1371/journal.pone.0068382

${ }^{7}$ Patrick M Markey and Charlotte N Markey, 'Vulnerability to Violent Video Games: A Review and Integration of Personality Research', Review of General $\begin{array}{llllll}\text { Psychology } & 14 & \text { (2010): } & 82-91 & \text { Viewed January } & 2015\end{array}$ http://www.apa.org/pubs/journals/releases/gpr-14-2-82.pdf

8 "'PewDiePie' Youtube Channel Page", Viewed January 2015, https://www.youtube.com/user/PewDiePie

9 Everett Rogers, Diffusion of Innovations (London: Simon and Schuster International, 2003)

${ }^{10}$ Brian Crecente, 'PewDiePie Isn't Just a Popular Let's Play YouTuber, He's the \$4M-a-year King of YouTube', Polygon.com, June 17 $7^{\text {th }} 2014$, Viewed January 2015 http://www.polygon.com/2014/6/17/5817118/how-much-does-pewdiepie-make

; Charlie Hall, 'Pewdiepie 'More Influential' Among Teens Than Katy Perry and Hollywood Elite', Polygon.com, August $7^{\text {th }}$ 2014, Viewed January 2014 http://www.polygon.com/2014/8/7/5980019/pewdiepie-more-popular-amongteens-than-traditional-celebrities

${ }^{11}$ Skate 3, British Columbia, Canada: EA Black Box, 2010. PlayStation 3, Xbox 360 ; Flappy Bird, Hanoi, Vietnam: GEARS Studios, 2013. iOS, Android, Amazon Fire TV

12 "Skate 3 Playstation 3 Metascore", Viewed January 2015, http://www.metacritic.com/game/playstation-3/skate-3

13 Christopher Dring, 'How Pewdiepie Fired Skate 3 Back Into the Charts', MCVUK.com, August $26^{\text {th }}$ 2014, Viewed January 2015 http://www.mcvuk.com/news/read/how-pewdiepie-fired-skate-3-back-into-thecharts/0137447

14 "Flappy Bird - Don't Play This Game", Viewed January 2015, https://www.youtube.com/watch?v=1Qz6xhlOt18

${ }^{15}$ Eliss Hamburger, 'Indie Smash Hit 'Flappy Bird' Racks Up \$50K Per Day in Ad Revenue', The Verge.com, Febuary $5^{\text {th }}$ 2014, View January 2015, http://www.theverge.com/2014/2/5/5383708/flappy-bird-revenue-50-k-per-daydong-nguyen-interview

16 "Flappy Bird iOS Metascore" Viewed January 2015, http://www.metacritic.com/game/ios/flappy-bird

; Mike Bertha, 'Everything You Need to Know About Your New Favourite Cell Phone Game, 'Flappy Bird', Philly.com, January 30 ${ }^{\text {th }}$ 2014, Viewed January 2015, 
http://www.philly.com/philly/blogs/trending/Flappy-Bird-app-game-iPhone-

Android-obsessed-cheats-impossible-Ironpants.html

${ }^{17}$ Vince Ingentio, 'Flappy Bird Creator To Take Game Down Tomorrow', IGN.com, Febuary $\quad 8^{\text {th }} \quad 2014, \quad$ Viewed January 2015, http://uk.ign.com/articles/2014/02/08/flappy-bird-creator-to-take-game-downtomorrow

; Dave Their, 'Flappy Bird' Price Skyrocketing on eBay', Forbes.com, Febuary $10^{\text {th }}$ 2014, Viewed January 2015, http://www.forbes.com/sites/davidthier/2014/02/10/flappy-bird-price-skyrocketingon-ebay/

; Harry McCracken, 'Where to Get Flappy Bird: On eBay, for \$900. Cheap!', TIME.com, February $9^{\text {th }} 2014$, Viewed January 2015 http://time.com/6073/whereto-get-flappy-bird/

${ }^{18}$ Fournier, Consumers and Their Brands

${ }^{19}$ Gamespot Staff, 'Hideo Kojima Exclusive Q\&A', Gamespot.com, May $20^{\text {th }} 2005$, Viewed January 2015, http://www.gamespot.com/articles/hideo-kojima-exclusiveqanda/1100-6126180/

${ }^{20}$ Metal Gear Acid, Tokyo, Japan: Konami Computer Entertainment Japan, 2005. PlayStation Portable

; Metal Gear Solid V: Ground Zeroes, Tokyo, Japan: Kojima Productions, 2014. PlayStation 3, PlayStation 4, Xbox 360, Xbox One, Microsoft Windows

21 Albert Bandura, 'Personal and Collective Efficacy in Human Adaptation and Change', Advances In Psychological Science, Volume 1: Social, Personal and Cultural Aspects: Social, Personal and Cultural Aspects Vol 1, ed. John G. Adair, David Bélanger and Kenneth L. Dion (East Sussex: Psychology Press, 1998) 51-71. 22 "Metal Gear Acid PSP Metascore" Viewed January 2015, http://www.metacritic.com/game/psp/metal-gear-acid

; "Metal Gear Solid V: Ground Zeroes PlayStation 4 Metascore" Viewed January 2015, http://www.metacritic.com/game/playstation-4/metal-gear-solid-v-groundzeroes

; Russ Frishtick 'Metal Gear Solid 5: Ground Zeroes Review: Cold War', Polygon.com, March $18^{\text {th }} 2014$, Viewed January 2015, http://www.polygon.com/2014/3/18/5519578/metal-gear-solid-5-ground-zeroes$\underline{\text { review }}$

; Jim Sterling 'Metal Gear Solid V: Ground Zeroes Review - Snake Oil', Escapistmagazine.com, 18 ${ }^{\text {th }}$ March 2014, Viewed January 2015, http://www.escapistmagazine.com/articles/view/video-

games/editorials/reviews/11133-Metal-Gear-Solid-V-Ground-Zeroes-Review-

Snake-Oil

${ }^{23}$ Frank M Bass, 'A New Product Growth for Model Consumer Durables', Management Science 15 (1969): 215-227, Viewed January 2015, 
http://www.uvm.edu/ pdodds/teaching/courses/2009-08UVM-

300/docs/others/everything/bass1969a.pdf

${ }^{24}$ Sonic the Hedgehog, Tokyo, Japan; Sonic Team, SEGA, 1991. Sega Genesis, Android, Game Boy Advance, iOS Devices, Java ME, Nintendo DS, Nintendo 3DS, Nintendo GameCube, PlayStation 2, PlayStation 3, PlayStation Network, PlayStation Portable, Sega Dreamcast, Sega Saturn, Wii Virtual Console, Windows, Xbox Live Arcade, Xbox, Xbox 360 ; Sonic the Hedgehog 2, Tokyo, Japan: Sonic Team, SEGA, 1992. Sega Genesis/Megadrive, PlayStation 2, Nintendo GameCube, Nintendo DS, Xbox, Mobile, Microsoft Windows, Virtual Console, Xbox Live Arcade, PlayStation Network, iOS, Android, Windows Phone

; Sonic the Hedgehog 3, Tokyo, Japan: Sonic Team, SEGA, 1994. Sega Genesis/Megadrive, Microsoft Windows, Nintendo DS, Wii Virtual Console, Xbox Live Arcade

; Sonic the Hedgehog and Knuckles, Tokyo, Japan: Sonic Team, SEGA, 1994. Sega Genesis/Megadrive, GameCube, PlayStation 2, PlayStation 3, Sega PC, Sega Saturn, Wii Virtual Console, Xbox, Xbox 360

; Sonic CD, Tokyo, Japan; Sonic Team, SEGA, 1993. Sega CD, Microsoft

Windows, Nintendo GameCube, PlayStation 2, Xbox Live Arcade, PlayStation

Network, iOS, Android, Windows Phone, Ouya

${ }^{25}$ Sonic Boom: Rise of Lyric, California, USA: Big Red Button Entertainment, El Segundo, 2014. Wii U

26 Shawn Taylor, 'SEGA Says No to Sonic Boom Review Copies', Nintendonews.com, November $11^{\text {th }}$ 2014, Viewed January 2015, http://nintendonews.com/2014/11/sega-sonic-boom-review-copies/

; Owen S Good, 'Sonic Boom Shows an Appreciation of Platforming', Polygon.com, $\begin{array}{llll}\text { June } \quad 2014, \quad \text { Viewed } & \text { January } & \text { 2015, }\end{array}$ http://www.polygon.com/2014/6/2/5770788/sonic-boom-preview-wii-u-3ds

; Keith Stuart, 'Sega Can Save Sonic the Hedgehog - Here's How', theguardian.com, 26 ${ }^{\text {th }}$ November 2014, Viewed January 2015, http://www.theguardian.com/technology/2014/nov/26/sega-sonic-the-hedgehog

27 "Sonic Boom: Rise of Lyric WiiU Metascore" Viewed January 2015, http://www.metacritic.com/game/wii-u/sonic-boom-rise-of-lyric

28 Jane McGonigal, Reality is Broken: Why Games Make Us Better and How They Can Change the World (UK:Vintage, 2012)

${ }^{29}$ Mary Flanagan, 'Making Games for Social Change', AI \& Soc 20 (2006): 493 505, Viewed January 2015, http://intelligentagent.com/RISD/FlanaganGamesSocChg.pdf

${ }^{30}$ Leigh Alexander, 'Gamers' Don't Have to be Your Audience. 'Gamers' Are Over', Gamasutra.com, August $28^{\text {th }}$ 2014, Viewed January 2014, http://www.gamasutra.com/view/news/224400/Gamers dont have to be_your_au dience Gamers are over.php 
31 Matt Hills, 'Transcultural Otaku: Japanese Representations of Fandom and Representations of Japan in Anime/Manga Fan Cultures', Media in Transition 2 Globalization and Convergence (2002), Viewed January 2015, http://cmsw.mit.edu/mit2/Abstracts/MattHillspaper.pdf

${ }^{32}$ Mihaly Csikszentmihalyi and Robert Kubey, 'Television and the Rest of life; A Systematic Comparison of Subjective Experience', The Public Opinion Quarterly $45 \quad$ (1981): 317-328, Viewed January 2015, http://xa.yimg.com/kq/groups/24960419/353080319/name/2748608.pdf

${ }^{33}$ George Gerbner et al, 'Living with Television: The Dynamics of the Cultivation Process', Perspectives on media effects (1986): 17-40, Viewed January 2015, http://wiki.commres.org/pds/CultivationTheory/LivingWithTelevision_TheDynami csoftheCultivationProcess.pdf

\section{Bibliography}

Alexander, Leigh. 'Gamers' Don't Have to be Your Audience. 'Gamers' Are Over'. Gamasutra.com, August $28^{\text {th }} \quad 2014$. http://www.gamasutra.com/view/news/224400/Gamers dont have to be your_au dience Gamers are over.php

American Psychological Association. Resolution on Violence in Video Games and Interactive Media. (2005) http://www.apa.org/about/policy/interactive-media.pdf

Bandura, Albert. 'Personal and Collective Efficacy in Human Adaptation and Change'. Advances In Psychological Science, Volume 1: Social, Personal and Cultural Aspects: Social, Personal and Cultural Aspects Vol 1, edited by John G. Adair, David Bélanger and Kenneth L. Dion, 51-71. East Sussex: Psychology Press, 1998.

Bass, Frank M. 'A New Product Growth for Model Consumer Durables'. Management $\quad$ Science $\quad 15 \quad$ (1969): http://www.uvm.edu/ pdodds/teaching/courses/2009-08UVM300/docs/others/everything/bass1969a.pdf

Bertha, Mike. 'Everything You Need to Know About Your New Favourite Cell Phone Game, 'Flappy Bird'. Philly.com, January $30^{\text {th }}$ 2014, Viewed January 2015, http://www.philly.com/philly/blogs/trending/Flappy-Bird-app-game-iPhone-

Android-obsessed-cheats-impossible-Ironpants.html

Crecente, Brian. 'PewDiePie Isn't Just a Popular Let's Play YouTuber, He's the \$4Ma-year King of YouTube'. Polygon.com, June $17^{\text {th }} 2014$. http://www.polygon.com/2014/6/17/5817118/how-much-does-pewdiepie-make 
Csikszentmihalyi Mihaly. and Kubey Robert. 'Television and the Rest of life; A Systematic Comparison of Subjective Experience', The Public Opinion Quarterly 45 (1981): 317-328. http://xa.yimg.com/kq/groups/24960419/353080319/name/2748608.pdf

Dean, Paul. 'Tropes vs Women in Video Games: Why it Matters' IGN, $31^{\text {st }}$ May 2013. http://uk.ign.com/articles/2013/05/31/tropes-vs-women-in-video-gameswhy-it-matters

Dring, Christopher. 'How Pewdiepie Fired Skate 3 Back Into the Charts'. MCVUK.com, August $26^{\text {th }}$ 2014. http://www.mcvuk.com/news/read/howpewdiepie-fired-skate-3-back-into-the-charts/0137447

Flanagan, Mary. 'Making Games for Social Change', AI \& Soc 20 (2006): 493-505. http://intelligentagent.com/RISD/Flanagan-GamesSocChg.pdf

"Flappy Bird - $\quad$ Don't Play This Game". https://www.youtube.com/watch?v=1Qz6xhlOt18

“Flappy Bird iOS Metascore". http://www.metacritic.com/game/ios/flappy-bird

Fournier, Susan. 'Consumers and Their Brands: Developing Relationship Theory in Consumer Research'. Journal of Consumer Research 24 (1998): 343-352. http://www.jstor.org/stable/pdfplus/10.1086/209515.pdf?acceptTC=true\&jpdConfi $\underline{\mathrm{rm}=\text { true } \&}$

Frishtick Russ. 'Metal Gear Solid 5: Ground Zeroes Review: Cold War'. Polygon.com, $\quad$ March $18^{\text {th }} \quad 2014$. http://www.polygon.com/2014/3/18/5519578/metal-gear-solid-5-ground-zeroes$\underline{\text { review }}$

Gamespot Staff. 'Hideo Kojima Exclusive Q\&A'. Gamespot.com, May $20^{\text {th }} 2005$. http://www.gamespot.com/articles/hideo-kojima-exclusive-qanda/1100-6126180/

Gentile, Douglas A., Anderson, Craig A., Yukawa, Shintaro., Ihori, Nobuko., Saleem, Muniba., Ming, Lim Kam., Shibuya, Akiko., Liau, Albert K., Khoo, Angeline.,. Bushman, Brad J., Huesmann, L. Rowell., Sakamoto, Akira. 'The Effects of Prosocial Video Games on Prosocial Behaviors: International Evidence from Correlational, Longitudinal, and Experimental Studies'. Pers Soc Psychol Bull. 35 (2009):

752-763.

http://www.ncbi.nlm.nih.gov/pmc/articles/PMC2678173/pdf/nihms-104172.pdf 
Gerbner, George., Gross, Larry., Morgan, Michael., Signorelli. 'Living with Television: The Dynamics of the Cultivation Process', Perspectives on media effects (1986):

http://wiki.commres.org/pds/CultivationTheory/LivingWithTelevision_TheDynami csoftheCultivationProcess.pdf

Good, Owen S. 'Sonic Boom Shows an Appreciation of Platforming'. Polygon.com, June $2^{\text {nd }} 2014$. http://www.polygon.com/2014/6/2/5770788/sonic-boom-previewwii-u-3ds

Hall, Charlie. 'Pewdiepie 'More Influential' Among Teens Than Katy Perry and Hollywood Elite'. $\quad$ Polygon.com, August $\quad 7^{\text {th }} \quad 2014$. http://www.polygon.com/2014/8/7/5980019/pewdiepie-more-popular-amongteens-than-traditional-celebrities

Hamburger, Eliss. 'Indie Smash Hit 'Flappy Bird' Racks Up \$50K Per Day in Ad Revenue'. The Verge.com, Febuary $5^{\text {th }} \quad 2014$. http://www.theverge.com/2014/2/5/5383708/flappy-bird-revenue-50-k-per-daydong-nguyen-interview

Hills, Matt. 'Transcultural Otaku: Japanese Representations of Fandom and Representations of Japan in Anime/Manga Fan Cultures'. Media in Transition 2 Globalization and Convergence http://cmsw.mit.edu/mit2/Abstracts/MattHillspaper.pdf

(2002)

Ingentio, Vince. 'Flappy Bird Creator to Take Game Down Tomorrow'. IGN.com, Febuary $8^{\text {th }}$ 2014. http://uk.ign.com/articles/2014/02/08/flappy-bird-creator-to-takegame-down-tomorrow

Locke, Simon. "'Fanboy" as a Revolutionary Category'. Journal of Audience \& $\begin{array}{lllll}\text { Reception Studies 9, } & \text { issue } \quad 2 & \text { (2012): } & \text { 835-854. }\end{array}$ http://www.participations.org/Volume\%209/Issue\%202/Locke.pdf

Markey, Patrick M. and Markey, Charlotte N. 'Vulnerability to Violent Video Games: A Review and Integration of Personality Research'. Review of General Psychology 14 (2010): 82-91. http://www.apa.org/pubs/journals/releases/gpr-14-2$\underline{\underline{82 . p d f}}$

McCracken, Harry. 'Where to Get Flappy Bird: On eBay, for \$900. Cheap!'. TIME.com, February $9^{\text {th }}$ 2014. http://time.com/6073/where-to-get-flappy-bird/ 
McGonigal, Jane. Reality is Broken: Why Games Make Us Better and How They Can Change the World. UK:Vintage, 2012.

"Metal Gear Acid PSP Metascore". http://www.metacritic.com/game/psp/metalgear-acid

"Metal Gear Solid V: Ground Zeroes PlayStation 4 Metascore". http://www.metacritic.com/game/playstation-4/metal-gear-solid-v-ground-zeroes

"PewDiePie Youtube Channel Page". https://www.youtube.com/user/PewDiePie

Rogers, Everett. Diffusion of Innovations. London: Simon and Schuster International, 2003.

"Skate 3 Playstation 3 Metascore". http://www.metacritic.com/game/playstation$\underline{3 / \text { skate-3 }}$

"Sonic Boom: Rise of Lyric WiiU Metascore". http://www.metacritic.com/game/wii-u/sonic-boom-rise-of-lyric

Sterling, Jim. 'Metal Gear Solid V: Ground Zeroes Review - Snake Oil"' Escapistmagazine.com, $18^{\text {th }} \quad$ March 2014. http://www.escapistmagazine.com/articles/view/videogames/editorials/reviews/11133-Metal-Gear-Solid-V-Ground-Zeroes-Review$\underline{\text { Snake-Oil }}$

Stuart, Keith. 'Sega Can Save Sonic the Hedgehog - Here's How'. theguardian.com, $26^{\text {th }}$ November 2014. http://www.theguardian.com/technology/2014/nov/26/segasonic-the-hedgehog

Taylor, Shawn. 'SEGA Says No to Sonic Boom Review Copies'. Nintendonews.com, November $11^{\text {th }}$ 2014. http://nintendonews.com/2014/11/segasonic-boom-review-copies/

Tear, Morgan J. and Nielson, Mark. 'Failure to Demonstrate That Playing Violent Video Games Diminishes Prosocial Behavior'. PLOS ONE Journal DOI: 10.1371/journal.pone.0068382

http://journals.plos.org/plosone/article?id=10.1371/journal.pone.0068382

Their, Dave. 'Flappy Bird' Price Skyrocketing on eBay'. Forbes.com, Febuary $10^{\text {th }}$ 2014. http://www.forbes.com/sites/davidthier/2014/02/10/flappy-bird-priceskyrocketing-on-ebay/ 


\section{Ludography}

Flappy Bird. Hanoi, Vietnam: GEARS Studios, 2013. iOS, Android, Amazon Fire TV

Metal Gear Acid. Tokyo, Japan: Konami Computer Entertainment Japan, 2005. PlayStation Portable

Metal Gear Solid V: Ground Zeroes. Tokyo, Japan: Kojima Productions, 2014. PlayStation 3, PlayStation 4, Xbox 360, Xbox One, Microsoft Windows

Skate 3. British Columbia, Canada: EA Black Box, 2010. PlayStation 3, Xbox 360

Sonic Boom: Rise of Lyric. California, USA: Big Red Button Entertainment, El Segundo, 2014. Wii U

Sonic CD. Tokyo, Japan; Sonic Team, SEGA, 1993. Sega CD, Microsoft Windows, Nintendo GameCube, PlayStation 2, Xbox Live Arcade, PlayStation Network, iOS, Android, Windows Phone, Ouya

Sonic the Hedgehog. Tokyo, Japan; Sonic Team, SEGA, 1991. Sega Genesis, Android, Game Boy Advance, iOS Devices, Java ME, Nintendo DS, Nintendo 3DS, Nintendo GameCube, PlayStation 2, PlayStation 3, PlayStation Network, PlayStation Portable, Sega Dreamcast, Sega Saturn, Wii Virtual Console, Windows, Xbox Live Arcade, Xbox, Xbox 360

Sonic the Hedgehog 2. Tokyo, Japan: Sonic Team, SEGA, 1992. Sega Genesis/Megadrive, PlayStation 2, Nintendo GameCube, Nintendo DS, Xbox, Mobile, Microsoft Windows, Virtual Console, Xbox Live Arcade, PlayStation Network, iOS, Android, Windows Phone

Sonic the Hedgehog 3. Tokyo, Japan: Sonic Team, SEGA, 1994. Sega Genesis/Megadrive, Microsoft Windows, Nintendo DS, Wii Virtual Console, Xbox Live Arcade

Sonic the Hedgehog and Knuckles. Tokyo, Japan: Sonic Team, SEGA, 1994. Sega Genesis/Megadrive, GameCube, PlayStation 2, PlayStation 3, Sega PC, Sega Saturn, Wii Virtual Console, Xbox, Xbox 360

Bradley James is a $\mathrm{PhD}$ student at Staffordshire University specialising in reward systems. He has presented and published several papers at the institution, where he 
also lectures at degree level across two campuses. Bradley has a multitude of skills as a journalist and writer, and is available to consult on game design, UX and UI.

Dr Bobbie Fletcher is an experienced project manager and has undertaken extensive research into Reward in Games, Reward and Demographics in Games, as well as Immersion and Audience interaction with Augmented Reality. Her $\mathrm{PhD}$ is in Mathematical Modelling and Simulation. 